\title{
PERSPECTIVES ON CANCER STEM CELLS IN OSTEOSARCOMA
}

\author{
Upal Basu-Roy ${ }^{1}$, Claudio Basilico ${ }^{1,2}$, and Alka Mansukhani ${ }^{1,2}$ \\ ${ }^{1}$ Department of Microbiology, New York University School of Medicine, 550 First Avenue, New \\ York, NY 10016
}

\begin{abstract}
Osteosarcoma is an aggressive pediatric tumor of growing bones that, despite surgery and chemotherapy, is prone to relapse. These mesenchymal tumors are derived from progenitor cells in the osteoblast lineage that have accumulated mutations to escape cell cycle checkpoints leading to excessive proliferation and defects in their ability to differentiate appropriately into mature boneforming osteoblasts. Like other malignant tumors, osteosarcoma is often heterogeneous, consisting of phenotypically distinct cells with features of different stages of differentiation. The cancer stem cell hypothesis posits that tumors are maintained by stem cells and it is the incomplete eradication of a refractory population of tumor-initiating stem cells that accounts for drug resistance and tumor relapse. In this review we present our current knowledge about the biology of osteosarcoma stem cells from mouse and human tumors, highlighting new insights and unresolved issues in the identification of this elusive population. We focus on factors and pathways that are implicated in maintaining such cells, and differences from paradigms of epithelial cancers. Targeting of the cancer stem cells in osteosarcoma is a promising avenue to explore to develop new therapies for this devastating childhood cancer.
\end{abstract}

\section{Keywords}

osteosarcoma; cancer stem cell; tumor initiating cell; mesenchymal tumors; bone cancer; Sox2; FGF; Wnt signaling

\section{Osteosarcoma- The Clinical Disease}

Osteosarcoma is the most common primary malignant bone tumor in children and adolescents, comprising almost $60 \%$ of all bone sarcomas [1;2]. It is an osteoid producing solid tumor that occurs more often in larger bones close to epiphyseal areas of rapid growth. The incidence of osteosarcoma is approximately $4-5$ children per year per million in the US. It shows a bimodal age distribution with a peak incidence of osteosarcoma in young adults. A second peak of incidence was identified in elderly adults where it is associated with defective bone remodeling $[3 ; 4]$ With the advent of chemotherapy, the long-term cure rate after surgery for non-metastatic osteosarcoma has risen from $25 \%$ to $60 \%$ [5]. However, despite advances in chemotherapy and surgery, the survival rate for osteosarcoma has

\footnotetext{
(C) 2012 Elsevier Ireland Ltd. All rights reserved.

2Corresponding author: Alka.Mansukhani@med.nyu.edu, ph: 212263 5906, fax: 212263 8276. Claudio.Basilico@med.nyu.edu, ph: 212263 5341, fax: 2122632714.

Conflict of interest: The authors declare no conflict of interest

Publisher's Disclaimer: This is a PDF file of an unedited manuscript that has been accepted for publication. As a service to our customers we are providing this early version of the manuscript. The manuscript will undergo copyediting, typesetting, and review of the resulting proof before it is published in its final citable form. Please note that during the production process errors may be discovered which could affect the content, and all legal disclaimers that apply to the journal pertain.
} 
reached a plateau and $40 \%$ of osteosarcoma patients eventually succumb to the disease. The majority of osteosarcoma are high grade and are often metastatic at presentation [6]. They are associated with poor prognosis and the overall survival rate for patients with advanced disease remains low at $20 \%$ [7;8]. A high proportion of patients will have a relapse due to metastasis to the lung, the primary site of osteosarcoma metastasis. Up to $20 \%$ of osteosarcoma patients present with detectable lung metastasis at initial diagnosis, whereas $80 \%$ of patients with only primary tumors develop metastasis in the lung following surgical resection [6]. Metastases are often resistant to conventional chemotherapy and current aggressive treatments pose a significant challenge and do not guarantee long-term survival [9]. A better understanding of osteosarcoma biology and pathogenesis is needed to advance the development of targeted therapies for both primary and metastatic osteosarcoma.

\section{Genetics of Osteosarcoma}

Molecular and cytogenetic analyses have detected a variety of alterations in osteosarcoma that include several complex chromosomal rearrangements often specific to each tumor [10]. Unlike Ewing's sarcoma, osteosarcoma is not associated with a specific oncogene or chromosomal rearrangement [11]. Comparative genomic hybridization analyses have identified several areas of DNA gain or loss, and oncogenes such as $M Y C, F O S$ and $M D M 2$, as well as $R E C Q$ helicase mutations have been associated with a small proportion of osteosarcoma. Some recurrent alterations may even have prognostic value [12]. The mutations associated with osteosarcoma have been extensively reviewed by Tang et al [13]. Despite extensive cytogenetic analysis, the common underlying genetic alterations responsible for disease development remain elusive [14]. The strongest genetic association for sporadic and hereditary osteosarcoma is with the retinoblastoma $(\mathrm{Rb})$ and $\mathrm{p} 53$ tumor suppressor genes. Li Fraumeni patients who carry mutations in p53 are predisposed to osteosarcoma and patients with $\mathrm{Rb}$ mutations have a 500 fold increased incidence of osteosarcoma compared to the general population.

Compelling evidence for the role of $\mathrm{Rb}$ and $\mathrm{p} 53$ in osteosarcomagenesis comes from genetically engineered mouse models that can recapitulate the human disease $([15 ; 16]$. Conditional knockout using Cre-lox technology to inactivate Rb and p53 in the osteoblast lineage leads to short-latency spontaneous metastatic osteosarcoma similar to human tumors in which the cells are arrested in their differentiation [17; 18]. These studies demonstrate the essential role of $\mathrm{p} 53$ inactivation and the cooperating effect of $\mathrm{Rb}$ disruption in the development of osteosarcoma. While it is evident that several other alterations must accrue on the path to an cancer development, the loss of $\mathrm{Rb}$ and p53 are critical events in this process. Interestingly, the barrier that the p53 pathway poses to tumorigenesis, is also becoming evident from studies in induced pluripotent cells, where p53 blocks reprogramming of somatic cells to pluripotent cells $[19 ; 20]$. One could speculate then that inactivation of these tumor suppressors in a tumor-initiating cell could permit aberrant dedifferentiation to a more primitive state of the progenitor cell that originates the osteosarcoma. Rb and p53 DNA are also sentinels of the DNA damage checkpoint pathway targeted by radiation which is another inducer of osteosarcoma [21]. Thus, osteosarcoma is associated with the accrual of multiple genetic alterations, of which only a few predisposing mutations have been identified.

\section{Osteosarcoma and the Cancer Stem Cell (CSC) Hypothesis}

Our view of cancer formation has increased in complexity over the past decade. Tumors are no longer viewed as homogenous masses of proliferating cells, each with identical genetic alterations, but more as a heterogeneous tissue that contains a hierarchy of cells, perhaps originating from a single cancer stem cell. Maintenance of the tumor is also dependent on a 
stromal cell component from the tumor microenvironment or niche that nurtures the growth of cancer cells [22].

There is accumulating evidence suggesting that tumors are partially refractory to standard radiation and chemotherapeutic regimens because of their heterogeneous composition. Most anti-cancer agents work on the premise that the high cell division rate of tumor cells makes them more susceptible to anti-proliferative treatments. However, this traditionally held view that arose from initial studies on the clonal origin of leukemias and of oncogenic viruses, and postulated that all cancer cells are fast-dividing and possess tumorigenic potential, has been challenged. This view, called the clonal evolution or stochastic model, posits that all cells within a tumor can repopulate a tumor. A subset of these cells may sequentially acquire additional genetic alterations that promote their survival, aggressiveness and metastatic ability $[23 ; 24 ; 25]$. In contrast, the cancer stem cell (CSC) hypothesis postulates that a small subpopulation of cancer cells drives tumor growth and metastasis. This subpopulation, also referred to as tumor-initiating cells (TIC), is thought to be resistant to treatment and can repopulate a tumor after cessation of chemotherapy. Over the last decade, evidence for the cancer stem cells hypothesis has accumulated alongside the parallel development of the concept that normal tissues are maintained by somatic stem cells. This has led to the sometimes uneasy alliance between stem cell and cancer biology. Though the name "cancer stem cell" is still considered controversial by stem cell orthodoxy which requires not only self renewal but also a stringent demonstration of multipotency in order to identify cells as stem cells, cancer biologists refer to such cells as the "stem cell fraction" of a tumor since these cells possess many canonical stem cell properties of self renewal and differentiation to more lineage restricted cell types through symmetric and asymmetric division. Besides the biological properties that CSCs share with normal stem cells, CSCs also express higher levels of drug transporters and possess higher DNA repair capacities making them especially resilient to standard anti-cancer regimens. Thus, knowledge of the biology of these cells- the mutations and epigenetic changes that cause them to originate, and the niches that enable their maintenance depends on the unequivocal identification and isolation of such cells.

Although the concept of cancer stem cells was first put forth in the 1950's, the strongest evidence of a cancer stem cell emerged in 1994 in seminal studies by Dick and colleagues who showed that rare $\mathrm{CD} 34^{+} / \mathrm{CD} 38^{-}$cells (frequency $10^{-5}-10^{-6}$ ) derived from a leukemia patient were sufficient to cause acute myeloid leukemia when transplanted in severe combined immunodeficiency (SCID) mice [26]. These experiments established the proof-ofprinciple experiment for a canonical cancer stem cell - the ability to regenerate a tumor from a single cell in vivo. Since then, there has been a concerted search for small population of CSCs in other cancers. The stemness properties of such cells are usually assessed based on their ability to grow clonally as spheres under serum-free conditions, to undergo symmetric and asymmetric division and be able to generate tumors in immunocompromised mice. Such cells have now also been identified in solid tumors of epithelial and neuro-ectodermal origin and more recently, in tumors of mesenchymal origin.

CSCs isolated from these different tumor types share some common characteristics such as drug resistance, ability to repopulate tumors and asymmetric division. These characteristics have been exploited to identify CSCs but given the differences in the tissue of origin, it is becoming evident that CSCs isolated from epithelial, neuro-ectodermal and mesenchymal tumors might have differential requirements for their maintenance and growth, exhibit diverse cell surface glycoproteins and differentially exploit signal transduction pathways.

The existence of CSCs in osteosarcoma was first demonstrated by Gibbs and colleagues who showed that human osteosarcoma samples and cell lines contain a sub-population $\left(10^{-2}\right.$ $10^{-3}$ ) of cells that are capable of growing in spherical, clonal clusters in suspension under 
serum-free conditions and have the properties of self renewal and multipotency [27]. These cell clusters, referred to as sarcospheres or osteospheres, can be dissociated and replated to form secondary spheres, and have the ability to undergo osteogenic and adipogenic differentiation. Further studies demonstrated that sphere-forming cells from osteosarcoma lines can initiate tumors, and are more drug-resistant to chemotherapeutic agents [28]. Cells with stem-like properties can also be separated by fluorescent or magnetic cell sorting based on the high expression of cell surface glycoprotein markers preferentially expressed on mesenchymal stem cells such as CD133 (prominin), CD 117(c-kit) and Stro-1 [29; 30]. Subsequent studies have revealed that a small CD133-positive population $\left(10^{-4}\right)$ from human osteosarcoma correlates with the sphere-forming ability and in vivo tumor-forming capacity in xenograft assays $[30 ; 31]$.

Correlations with stem cell markers have been recently corroborated in mouse models of osteosarcoma. In mice with conditional deletion of the $\mathrm{Rb}$ and p53 genes in the osteoblast lineage, osteosarcoma originates with almost $100 \%$ penetrance. Cells isolated from these murine tumors are multipotent, possess a significant sphere-forming fraction with high expression of the mouse stem cell surface antigen, Sca-1. In these tumor cells, Sca-1 expression correlates with sphere and tumor-forming ability as well as multipotency [17; 32]. Besides the sphere-forming assay, the CSC content of osteosarcoma has also been assessed by assays that harness other properties of stem cells such as the ability to retain or efflux dyes or to exhibit high aldehyde dehydrogenase (ALDH1) activity $[33 ; 34 ; 35 ; 36$; 37]. These assays tend to identify a higher proportion of the cells which likely contain the CSC fraction and perhaps other progenitor cells that maintain these properties.

\section{Issues in Isolation and Functional Characterization of CSCs from Osteosarcoma}

Most techniques for the isolation of CSCs from osteosarcoma rely on methods that exploit the differences between CSCs and bulk of the tumor population. A major concern of such methods is the assumption that such differences are irreversible and that there exists primarily one type of CSC population. Detailed reviews of the different methods used for isolation and identification of osteosarcoma stem cells have been provided [13; 38]. Studies utilizing different methods for osteosarcoma CSC enrichment are summarized in Table 1. We focus here on highlighting some of the issues and caveats with each of these methods.

\subsection{Isolation based on expression of surface markers}

Such isolation strategies rely on the differential expression of surface markers on the CSC fraction of the tumor cells. In tumors of mesenchymal origin, markers that are commonly expressed on mesenchymal stem cells have been employed to isolate osteosarcoma CSCs. Of these, only a few have been useful in isolating a small fraction of cells with CSC characteristics. Unfortunately, normal stem cells in mesenchymal tissues do not have a welldefined hierarchical organization of cells as in the hair follicle, intestine or hematopoietic systems, and there is no clear consensus on the best mesenchymal stem cell markers to use $[39 ; 40]$. As evident from the studies in Table 1, multiple surface markers, singly and in combination, have been used to identify and isolate CSCs from both established cell lines, and disaggregated human tumor samples. However, these results need to be interpreted with caution since marker expression is highly dependent on the cell line used (freshly isolated tumor sample, primary cell line, established cell line), and on the extent of passaging (passaged in vitro or in vivo). Additionally, marker expression differs between species and is variable based on the method of isolation (enzymatic versus mechanical disaggregation) since proteolytic cleavage of surface proteins can alter marker-dependent isolation. This is made clear from studies that demonstrate differing fractions of CD133-positive CSCs based 
on culture conditions [41]. As seen in Table 1, different markers used in these studies identify a variable content of putative CSCs. Passage in culture is also likely to be responsible for expanding this population. Therefore, given the lack of definitive markers for mesenchymal-derived CSCs, and various factors affecting their expression, CSCs determination based on surface marker expression cannot be interpreted in isolation but needs to be correlated with functional aspects of CSCs. Furthermore, different subpopulations of cells are likely being identified with different surface markers which could indicate that more than one type of stem cell exists in the bulk population. Although there is no available functional distinction between these, their existence is feasible. The emerging situation in normal tissues indicates that a hierarchy of stem cells coexist with quiescent and active stem cells making up the stem cell population [42], and recent data have uncovered a more fluid situation in which stem cell populations actually have the potential to interconvert [43].

\subsection{Isolation based on intrinsic cellular properties}

Dye retention-A commonly held assumption is that CSCs are relatively quiescent with slow proliferation rates and undergo asymmetric cell division. PKH26 and PKH67 are lipophilic dyes that uniformly label the cell membrane and partition equally into the two daughter cells after a labeled cell has undergone cell division. Thus, the rate of dye retention is inversely proportional to the rate of cell division. While a slow dividing cell effectively retains the dye, faster diving cells rapidly dilute the dye from their membrane. Since CSCs are capable of asymmetric division, it is assumed that the quiescent CSC retains the membrane label for longer periods as compared to the more differentiated daughter cells that divide rapidly and form the bulk of the tumor population. This technique was used to isolate PKH26+ CSCs from established human osteosarcoma cells [33]. Gene expression profiling reveals that the PKH26+ represents more immature cells as compared to the overall adherent cell population. However this PHK26+ fraction is much larger than the CD133+ fraction, again pointing to the identification of different subpopulations of cells with different identification methods.

Dye exclusion and Side Population-Several reports have demonstrated that CSCs are drug-resistant due to higher expression of drug transporters such as the $\mathrm{ABC}$ multidrug efflux transporters [44; 45]. This property has been utilized to isolate osteosarcoma CSCs from both established cell lines [34] and biopsied human osteosarcoma samples [35], based on their ability to exclude fluorescent DNA-binding dyes such as Hoechst33342. The dyeexcluding population is often referred to as the side population (SP). The SP from established bone sarcomas contained the sphere-forming population, and could also rapidly initiate tumors at a higher frequency. Additionally, the SP was able to undergo asymmetric division since they gave rise to both a SP fraction and a non-SP-fraction [34; 35].

Aldehyde Dehydrogenase (ALDH1) activity-The search for a universal marker for normal and cancer stem cells has yielded the drug detoxification enzyme, aldehyde dehydrogenase (ALDH1) as a possible candidate [46; 47]. The identification method (Aldefluor assay) relies on ALDH1 enzymatic activity to convert a non-fluorescent substrate to a fluorescent one, which allows isolation of ALDH1+ cells by fluorescent activated cell sorting. ALDH1+ osteosarcoma cells were found to be enriched in the sphere-forming fraction [36], and were associated with a more aggressive, tumor-forming population [37]. The ALDH1 assay has not been extensively used in osteosarcoma and can depend on the membrane of the cell type in some tissues where ALDH1+ cells are slower proliferating and have decreased ability to migrate. 
A caveat of all these assays is that they depend on two main assumptions that may not be universally applicable to CSCs from different tumors - a) that CSCs proliferate more slowly that the rest of the population b) that CSCs retain or exclude dyes differentially than the rest of the population.

\subsection{Functional Characterization of Osteosarcoma Stem Cells}

Functional characterization of CSCs are typically stringent assays that utilize two main aspects of such stem cells: a) the ability to give rise to a tumor that is similar to the original tumor in an immunocompromised host and b) the ability to give rise to cells of different lineages that compose the tissue of origin. Such functional characterization is usually a sequel to isolation techniques and is an absolute requisite to establish the identity of CSCs. In the studies described in the previous section, the marker used to isolate osteosarcoma CSCs was usually correlated with in vivo tumorigenicity (Table 1). The ability to form sarcospheres/osteospheres has been demonstrated to be well-correlated with the ability to form tumors in xenograft assays [33].

Limiting Dilution Assay (LDA) - This is the gold standard for establishing the identity of a tumor cell as a CSC. This assay is dependent on the ability of CSCs to form tumors in a dose-dependent manner that exhibits a linear relationship. In other words, a tumor cell is designated a CSC if it can initiate tumors at a much higher frequency and at lower cell numbers, as compared to the bulk tumor fraction or other cells. The validity of a limiting dilution assay is highly dependent on the linearity of the cell number-tumor frequency relationship, strain of the murine model, lack of an immune response that is an important regulator of tumor growth in vivo and presence of species-specific signals, and thus should be interpreted with caution $[48 ; 49 ; 50]$. Furthermore, given the intimate association of the tumor with its microenvironment, the site of injection also contributes to the efficiency of tumor initiation. Thus, orthotopic models in which cells are delivered directly to a bony niche may be a preferred site for assessing osteosarcoma CSCs [50]. The LDA assay can be applied to assess sphere formation in vitro. [51]. Although the mechanism by which stem cells preferentially form clonal spheres is mostly unknown, the assay is based on assessing the self-renewing populations of tumor cells that are able to grow in suspension under serum-free conditions. However, the sphere-formation assay has come under criticism for the followings reasons: 1) inability to distinguish it from aggregation at higher cell densities 2 ) inability to detect quiescent stem cells [52]. Establishment of clonality can be difficult, especially at higher cell densities, where clumping is observed. However, this can be averted by incorporating a LDA approach to establish that a single cancer stem cell can give rise to primary and then secondary spheres. We have effectively incorporated LDA along with a sphere-formation assay to demonstrate that Sca-1+ correlates with the sphere-forming ability of mouse osteosarcoma CSCs and with the expression of the stem cell transcription factor, Sox2. [32].

Multipotency-Unlike the bulk tumor fraction, CSCs undergo symmetric and asymmetric division to differentiate into several cell types that can be found in the original tissue and are therefore considered multipotent. While the definition of a canonical CSC does not include multipotency, it is an essential feature of the stem cell dogma [53]. Like MSCs, osteosarcoma CSCs also can differentiate into osteoblasts, adipocytes and chondrocytes under appropriate stimuli. Osteosarcoma CSC are relatively easy to characterize via multipotency assays due to the simplicity of differentiation protocols and identification of the differentiated cell types. These in vitro assays are generally conducted after markerbased separation to characterize the stem- and non-stem fraction. 
Thus the assays for multipotency in combination with LDA analysis provides the best available assessment for CSCs. Whether the better control cells against which these CSCdelineating parameters are assessed are the total adherent population, or marker negative cells, would depend on the proportion of CSCs within the population.

\section{The Case for Pluripotency Factors: Correlation and Causation}

It is a generally accepted axiom that cancer cells are in a relatively undifferentiated and more stem-like state. Several groups have reported that mRNAs for pluripotency-associated embryonic stem cell factors such as Oct4, Sox 2 and Nanog are preferentially expressed in the subset of sphere-forming, stem-like cells in human osteosarcoma and osteosarcoma cell lines [28; 30; 54], as well as in canine osteosarcoma [55]. These findings added weight to the notion of "stemness" in the sphere-forming population. Levings et al found that an Oct4promoter-GFP construct was highly expressed in xenografts and in rapidly dividing cells in $40-60 \%$ of the tumor mass [56]. Clonal isolates of GFP+ cells were highly tumorigenic compared to the rest of the population. While these studies suggest a correlation between expression of these pluripotency genes and stemness, a serious caveat in the OCT4-GFP experiments is the inability to detect authentic endogenous OCT4 expression [57].

The first evidence that expression of an embryonic stem cell pluripotency transcription factor played an important role in osteosarcoma stem cells comes from osteosarcoma in mice with the conditional deletion of p53 and $\mathrm{Rb}$. We found that tumor cells positive for the mouse MSC marker Sca-1, have enhanced sphere-forming capacity, and express the pluripotency transcription factor, Sox2. Sphere forming cells are enriched for Sca1 and Sox2 expression but exhibit decreased expression of Runx 2 and OSX markers of osteoblastic differentiation. We found no evidence of Oct4 expression. Knockdown of Sox 2 expression by shRNA led to loss of the sphere-forming ability and to loss of tumorigenic potential of the cells. Knockdown of Sox 2 also caused decreased Sca-1 expression and an increase in cell cycle inhibitors p21 and p27, thus reestablishing the osteogenic differentiation program. Sox 2 was also expressed in human osteosarcoma and osteosarcoma cell lines as well as in cells from freshly biopsied patient samples. Sphere forming ability in these human cells was also dependent on Sox 2 expression [32]. These findings strongly support the idea that osteosarcoma contains a de-differentiated cell population of primitive cells that has lost its osteoblastic properties. Importantly, this is the first demonstration that Sox2, a pluripotency maintaining factor, is required for self renewal and maintenance of cancer stem cells in osteosarcoma. [32].

Sox 2 expression closely correlates with that of Sca-1. Since Sox 2 is a nuclear protein that cannot be used to sort live cells we sorted cells into Sca- $1^{\mathrm{HI}}$ and Sca- $1^{\mathrm{LO}}$ fractions by Sca-1based magnetic separation, and FACS sorting, (Sca- $1^{\mathrm{HI}} \mathrm{Sox}_{2}{ }^{\mathrm{HI}}$ and $\left.\mathrm{Sca}-1^{\mathrm{LO}} \mathrm{Sox}{ }^{\mathrm{LO}}\right)$. The Sca- $1^{\mathrm{HI}}$ Sox $2^{\mathrm{HI}}$ fraction formed spheres more efficiently than $\mathrm{Sca}-1^{\mathrm{LO}} \mathrm{Sox} 2^{\mathrm{LO}}$ fraction, expressed very low levels of the osteoblast markers RUNX2 and osterix (OSX) and was essentially blocked in osteogenic differentiation. Interestingly, they had greater adipogenic potential than the Sca- $1^{\mathrm{LO}} \mathrm{Sox} 2^{\mathrm{LO}}$ cells. In contrast, the Sca- $1^{\mathrm{LO}}$, Sox $2^{\mathrm{LO}}$ fraction expressed significant levels of RUNX2 and OSX RNA and was capable of osteogenic differentiation. Upon passaging, $\mathrm{Sca}-1^{\mathrm{HI}} \mathrm{Sox} 2^{\mathrm{HI}}$ cells could give rise to Sca-1 ${ }^{\mathrm{LO}}$, Sox $2^{\mathrm{LO}}$ cells, but we did not find evidence of the reverse. This result indicates that Sox $2 / \mathrm{Sca}-1$ expression mark a population of stem-like cells but have maintained the ability to undergo symmetric and asymmetric division but that are defective in osteoblastic differentiation and preferentially enter the adipocytic fate [32].

Thus mouse and human osteosarcoma contain at least two populations of cells, with high Sox 2 expression marking cells with stem cell properties, and blocked in osteogenic 
differentiation, while low Sox 2 expressing cells as well as Sox 2 depleted cells can differentiate into mature osteoblasts and show activation of the Wnt pathway. These findings support the hypothesis that Sox 2 marks a population of osteosarcoma stem cells that, despite other mutations, maintain a requirement for Sox 2 for tumor initiation. Agents that inactivate Sox 2 could represent a new avenue for targeting osteosarcoma CSCs.

\section{The Osteoblast Differentiation Program: Disruption in Osteosarcoma}

Cancer stem cells share some properties with their normal counterparts and tumor formation has been likened to anomalous organogenesis [58]. The heterogeneous nature of osteosarcoma tissue indicates the presence of cells arrested at different stages of differentiation, and its' development coincides with periods when bone undergoes rapid growth or remodeling. MSCs are somatic stem cells that can differentiate into several lineages including adipocytes, osteoblasts or chondrocytes, which can further undergo proliferation, terminal differentiation or apoptosis [59; 60;61]. During bone formation, immature cells of the osteoblast lineage differentiate into mature osteoblasts that are responsible for synthesis, deposition and mineralization of matrix to form bone [62]. Primitive osteoprogenitors arise from multipotent mesenchymal stem cells that commit to the osteoblast lineage and differentiate to preosteoblasts and mature osteoblasts. Few markers are known that can be used to distinguish differentiation stages along this lineage. The earliest known marker and a key regulator of osteoblast commitment is the transcription factor RUNX2/CBFA1, while osterix (OSX)/SP7, another crucial regulator of osteoblastogenesis, functions downstream of RUNX2. As preosteoblasts expressing RUNX2 and OSX differentiate further along the osteoblast lineage, they gradually stop proliferating, as they synthesize and deposit matrix proteins, notably Collagen1. Differentiation then proceeds to mature osteoblasts along with the expression of osteocalcin (OCN). Finally the matrix is mineralized to generate bone (Figure 1).

Although osteosarcomas are heterogeneous tumor masses interspersed with osteoid and bone, the disease state is generally characterized by increased proliferation and defective differentiation. Loss of differentiation is a prognostic feature of high grade osteosarcoma while low grade disease is associated with more differentiated morphology. Several studies including ours point to a clear link between tumorigenesis and defective differentiation in osteosarcoma. The two tumor suppressors, $\mathrm{Rb}$ and $\mathrm{p} 53$, that are commonly inactivated in osteosarcoma, are also required for controlled osteoblast differentiation. The $\mathrm{Rb}$ protein interacts with and increases the transcriptional activity of RUNX2, thereby increasing osteoblast differentiation $[63 ; 64]$. These findings have been corroborated by bone-specific $\mathrm{Rb}$ knockout mice that exhibit impaired skeletal development with increased numbers of defective osteoprogenitors that are unable to undergo terminal cell cycle exit [65; 66]. In fact, $\mathrm{Rb}$ deficient osteoblasts have an increased capacity to form multipotent spheres [66]. Similar trends have been reported in bone-specific p53 knockout mice that show defective bone differentiation along with a high propensity for the development of osteosarcoma [67; 68]. It is highly likely that $\mathrm{Rb}$ and $\mathrm{p} 53$ mutations disrupt the bone differentiations program, thereby selecting for immature progenitors with defective DNA damage checkpoints and a propensity to accumulate further mutations.

Molecular evidence for the inverse relationship between differentiation and tumorigenesis was described by Hinds and colleagues who showed that the RUNX2 and p27 differentiation pathway is disrupted in osteosarcoma to maintain the undifferentiated state [69]. New evidence from an unrelated pathway supporting this notion comes from Williams et al, who recently demonstrated that osteosarcomas preserve a deubiquitination mechanism in common with mesenchymal stem cells. They found that ID (inhibitors of DNA binding) proteins, that antagonize the $\mathrm{Rb}$ pathway, are stabilized by the deubiquitinating enzyme 
USP1. High levels of ID proteins promoted the stem cell features and blocked osteoblastic differentiation in mesenchymal stem cells, and USP1 knockdown in osteosarcoma led to ID destabilization, growth arrest and differentiation [70]. Thus, although osteosarcoma stem cells must have some capacity to undergo asymmetric division and give rise to more differentiated daughter cells, osteosarcoma is characterized as a disease of defective differentiation [71].

\subsection{Cell of Origin}

Although most investigators assume that osteosarcoma originate from MSCs, the stage of the cell of origin remains difficult to pinpoint [13; 72]. Mouse models of spontaneous osteosarcoma in which $\mathrm{Rb}$ and p53 are inactivated in the osteoblast lineage, trace the cell of origin to osteoprogenitors. This is because the OSX-Cre transgene that mediates the excision of $\mathrm{Rb}$ and $\mathrm{p} 53$ floxed alleles, is driven by the osterix promoter that is expressed in osteoprogenitor cells. This suggests that osteosarcomas derive from a more restricted uni- or bipotent preosteoblast. However, it cannot be ruled out that the transgene may be expressed more broadly than the endogenous osterix promoter and may be expressed at more immature stages. Alternatively, the loss of Rb and p53 in a CSC may confer the ability to dedifferentiate to a more primitive state. Thus, whether CSC from osteosarcoma retain the ability to form multiple lineages, because they represent a de-differentiated fraction of osteoprogenitors that re-acquire MSC-like properties, or whether they retain multipotency because they derive from MSCs, remains to be elucidated (Figure 1).

\section{Signaling Factors that Influence Osteosarcoma CSCs}

An important component of the osteoblast differentiation program is the stem cell niche of the bone marrow. Bone marrow is a source of hematopoietic and mesenchymal stem cells and these two populations can be differentiated based on phenotypic and functional assays [73]. MSCs could maintain osteosarcoma cells in an undifferentiated state through secretion of cytokines such as interleukin-6 [74]. Recent work by Brune et al suggest that mesenchymal stem cells (MSCs) isolated from human osteosarcoma samples are genetically distinct from tumor cells, suggesting that maintenance of a separate MSC niche might be crucial in maintaining osteosarcoma cells in an undifferentiated state [75].

Apart from mesenchymal stem cells, the bone marrow is a rich source of factors that influence the bone differentiation program [76; 77]. Several signaling pathways such as Hedgehog, Notch and MAP kinase play a role in maintaining stem cells in the osteoblast lineage and may play a role in maintaining osteosarcoma CSCs, while BMPs that normally have a pro-differentiation function, have been reported to decrease osteosarcoma CSCs [78]. Fibroblast growth factor (FGF) signaling have been implicated in the maintenance of the cancer stem cell niche [79], and serve as a potential mechanistic link to the development of osteosarcoma stem cells. The FGFs function by binding to their cognate fibroblast growth factor receptors, (FGFRs) [80]. The finding that activating mutations in FGFRs cause a number of human autosomal dominant skeletal disorders provided clear evidence for the importance of FGF signaling in bone-development [80; 81]. FGF stimulates proliferation and blocks differentiation in immature osteoblasts [82;83], and induces the expression of Sox2. [84]. FGF signaling also induces proliferation of MSCs [85]. In There is emerging evidence that FGF signaling may play a role in maintaining osteosarcoma cells. FGF stimulation enhances proliferation of human osteosarcoma cells [86], and the FGFRs have been reported to be overexpressed in human osteosarcoma samples [87]. Treatment with inhibitors of FGF signaling leads to decreased Sox 2 expression and decreased proliferation in mouse osteosarcoma cells [32]. A recent report points to a role for stromally-derived FGF in maintaining the immature state and aggressiveness of osteosarcoma in a mouse model [88]. 
Wnt signaling plays an important role in bone development and several studies have established that Wnt signaling promotes osteoblast differentiation and bone formation. [89; 90]. In the canonical Wnt pathway, the transcription of Wnt target genes is regulated by accumulation of nuclear $\beta$-catenin. The binding of the Wnts to their receptors blocks the phosphorylation and degradation of $\beta$-catenin which is translocated to the nucleus to regulate Wnt target genes $[90 ; 91]$ While Wnt activation has been linked to cancer development in cells of epithelial origin, such as colon cancer, its role in mesenchymal tumors is likely be tumor-suppressive [92; 93]. The reports on Wnt signaling have generated some controversies in the literature about its activation or repression in osteosarcoma. Although the inactivation of a Wnt inhibitor, Wif-1, has been associated with radiationinduced osteosarcoma [94] implying deregulation of Wnt signaling, other groups have shown that Wnt signaling is down-regulated in osteosarcoma [95; 96]. In contrast to Matushansky et al who found that Wnt is inactive in a variety of human sarcomas, Vijay Kumar et al reported that Wnt signaling was active in fifty percent of human sarcomas and cell lines examined [97]. One reconciling explanation for these findings could be the heterogeneous nature of osteosarcoma and the differentiation stages of the cells examined. Wnt signaling would be expected to be active in more differentiated cells within the tumor.

In line with the findings of Matushansky et al [92], our studies clearly point to a tumor suppressive role for Wnt signaling in osteosarcoma. Using mouse and human osteosarcoma cells bearing a Wnt reporter gene, we found that that Wnt signaling is inactive in sphere forming stem cells. Knockdown of Sox 2 leads to induction of Wnt signaling along with the ability to undergo osteogenic differentiation [32].

Our data also suggest that FGF and Wnt signaling have opposing functions in osteosarcoma. FGF increases osteosarcoma sphere formation [32], and along with Sox2, FGFR2 expression is enriched in the sphere-forming fraction. Thus FGF could increase the stem population while more Wnt signaling is associated with differentiation which could maintain the osteosarcoma stem cell population. In line with these observations, we find that activation of Wnt signaling through the inhibition of the glycogen synthase kinase (GSK3 $\beta$ ) (with CHIR99201) in human epithelial (colon cancer HCT116) and a human osteosarcoma (NYU1-established in our laboratory) cell line provides contrasting results: while activation of Wnt signaling significantly increases the number of spheres formed by a colon tumor cells, osteosarcoma cells show a dramatic decrease in the number of spheres formed when Wnt is active (Figure 2). In several studies examining the effect of Wnt signaling on CSC derived from epithelial tumors, sphere formation is increased by Wnt activation and decreased by Wnt inhibition [98; 99; 100; 101] (Figure 2). Thus the effect of Wnt signaling is dependent on cellular context [93]

We have also found that Wnt signaling can decrease the amount of Sox 2 protein in osteosarcoma further pointing to the antagonism between the pro-proliferation and tumorigenicity function of Sox 2 and differentiation-inducing function of Wnt [32]. It remains to be determined whether the malignant state can be suppressed by activating Wnt signaling and suppressing Sox 2 in osteosarcoma cancer stem cells.

\section{Conclusions and Future Perspectives}

Since the discovery of oncogenes and tumor suppressor genes established the genetic nature of cancer, the cancer stem cell hypothesis is probably the only really novel notion that has inspired cancer research in the last decade. This hypothesis, imperfect as it is, has found considerable support form the studies of osteosarcoma, a highly aggressive tumor derived from the osteoblast lineage. Numerous laboratories have identified a subpopulation of human and murine osteosarcoma cells which express stem cell markers, are capable of 
tumor formation, and can form spheres in suspension culture. Differently from adult stem cells, which have a finite life span, such cells are immortal, as they carry numerous mutations (most commonly affecting the p53 and Rb pathways) that make them capable of continuous self-renewal.

A property of CSC that has been consistently described for tumors of epithelial origin, that they are slow-growing, and relatively quiescent, has not generally been found in osteosarcoma CSC, that, with few exceptions, have been reported to be growing faster than the rest of the tumor population. It is possible that CSC of mesenchymal origin differ from those of epithelial cancers. An attractive hypothesis that could reconcile these observations has been suggested by work indicating that adult stem cells can exist in a quiescent as well as in an active state, where the cells cycle but are long lived, in a continuous equilibrium. The major role of quiescent cells would be to replace the "damaged" active population. Bias in the methods of isolation and identification of CSC could inadvertently focus on one or another type of cell. Alternatively, it is possible that, depending on the number and nature of the oncogenic mutations, the original stem cell clone could evolve into a population where the relatively quiescent or the active CSC predominate. In fact, the sphere formation assay itself, may not select for quiescent stem cells, but a faster-self renewing population [52]. A similar bias could be responsible for the very varied estimates of the frequency of CSCs in the tumor population. In breast cancer, a high frequency of CSCs characterizes the most aggressive and advanced cancers [102].

Another important question that has not often been addressed in osteosarcoma is whether the asymmetric division of CSC is unidirectional, i.e. whether more differentiated progenitors can dedifferentiate back to CSC. In principle, this should be highly possible, since the expression of only a few transcription factors is sufficient to convert fibroblasts into induced pluripotent cells. However, we found such dedifferentiation does not occur spontaneously in culture. It cannot be excluded however that appropriate stimuli could achieve this conversion. For example, it will be interesting to know, whether FGF signaling, which induces Sox 2 expression, can promote dedifferentiation of osteosarcoma progenitors that express very low levels of Sox2.

Controversial reports have been made on the role and effect of Wnt signaling in osteosarcoma. The concept that Wnt signaling may be oncogenic in osteosarcoma is in line with what found in some epithelial cancers, but contrasts with the clear pro-differentiating effect of Wnt signaling in normal osteoblasts. Such an observation could derive from the examination of osteosarcoma where the non-CSC portion is predominant, as examination of Wnt signaling in CSC fraction shows that it is inactive, but it is indeed active in the nonCSC, more differentiated osteosarcoma cells. Alternatively, there may be different types of osteosarcoma, perhaps depending on the type of cell where the initial oncogenic event took place. Future experiments using Wnt inhibitors or activators may shed light on this controversy.

The issue of a stem cell signature is of great importance towards finding therapies targeted to CSC. Surprisingly, little has emerged this area, with the exception of a few reports.

Salinomycin, a K ionophore, was reported to be a potential selective killer of osteosarcoma CSC [103], and immunotherapy with modified lymphocytes has been reported to eliminate osteosarcoma CSCs [104]. Importantly, many markers of osteosarcoma CSC identified so far are molecules that are probably not critical to maintain stem cell viability or self-renewal, but only indicative of their differentiation state. The discovery that Sox 2, a transcription factor associated with stemness in many organs, is overexpressed in osteosarcomas and is required for their viability and tumorigenicity gives hope that other factors critical for CSC may be identified and targeted for therapy. Future therapies for improving current outcomes 
for osteosarcoma patients will likely combine cytotoxic drugs, which eliminate the bulk of tumor cells, with CSC-targeting therapy. With more accurate identification of the CSC population and further elucidation of the molecular pathways they depend on for survival, targeted drug therapies for osteosarcoma should be on the horizon.

\section{Acknowledgments}

This work was partly supported by PHS Grants AR051358 from the NIAMS and DE013745 from the NIDCR. AM is a recipient of a St Baldrick's Research Award and UBR was supported by a grant from the Children's Cancer Research Fund.

\section{References}

1. Cormier JN, Pollock RE. Soft tissue sarcomas. CA Cancer J Clin. 2004; 54:94-109. [PubMed: 15061599]

2. Heare T, Hensley MA, Dell'Orfano S. Bone tumors: osteosarcoma and Ewing's sarcoma. Curr Opin Pediatr. 2009; 21:365-372. [PubMed: 19421061]

3. Hansen MF, Seton M, Merchant A. Osteosarcoma in Paget's disease of bone. J Bone Miner Res. 2006; 21(Suppl 2):P58-63. [PubMed: 17229010]

4. Ottaviani G, Jaffe N. The epidemiology of osteosarcoma. Cancer Treat Res. 2009; 152:3-13. [PubMed: 20213383]

5. Caudill JS, Arndt CA. Diagnosis and management of bone malignancy in adolescence. Adolesc Med State Art Rev. 2007; 18:62-78. ix. [PubMed: 18605391]

6. Marina N, Gebhardt M, Teot L, Gorlick R. Biology and therapeutic advances for pediatric osteosarcoma. Oncologist. 2004; 9:422-441. [PubMed: 15266096]

7. Meyers PA, Heller G, Healey J, Huvos A, Lane J, Marcove R, Applewhite A, Vlamis V, Rosen G. Chemotherapy for nonmetastatic osteogenic sarcoma: the Memorial Sloan-Kettering experience. J Clin Oncol. 1992; 10:5-15. [PubMed: 1370176]

8. Meyers PA, Schwartz CL, Krailo M, Kleinerman ES, Betcher D, Bernstein ML, Conrad E, Ferguson W, Gebhardt M, Goorin AM, Harris MB, Healey J, Huvos A, Link M, Montebello J, Nadel H, Nieder M, Sato J, Siegal G, Weiner M, Wells R, Wold L, Womer R, Grier H. Osteosarcoma: a randomized, prospective trial of the addition of ifosfamide and/or muramyl tripeptide to cisplatin, doxorubicin, and high-dose methotrexate. J Clin Oncol. 2005; 23:2004-2011. [PubMed: 15774791]

9. PosthumaDeBoer J, Witlox MA, Kaspers GJ, van Royen BJ. Molecular alterations as target for therapy in metastatic osteosarcoma: a review of literature. Clin Exp Metastasis. 2011; 28:493-503. [PubMed: 21461590]

10. Bridge JA, Nelson M, McComb E, McGuire MH, Rosenthal H, Vergara G, Maale GE, Spanier S, Neff JR. Cytogenetic findings in 73 osteosarcoma specimens and a review of the literature. Cancer Genet Cytogenet. 1997; 95:74-87. [PubMed: 9140456]

11. Sandberg AA, Bridge JA. Updates on the cytogenetics and molecular genetics of bone and soft tissue tumors: osteosarcoma and related tumors. Cancer Genet Cytogenet. 2003; 145:1-30. [PubMed: 12885459]

12. Smida J, Baumhoer D, Rosemann M, Walch A, Bielack S, Poremba C, Remberger K, Korsching E, Scheurlen W, Dierkes C, Burdach S, Jundt G, Atkinson MJ, Nathrath M. Genomic alterations and allelic imbalances are strong prognostic predictors in osteosarcoma. Clin Cancer Res. 2010; 16:4256-4267. [PubMed: 20610556]

13. Tang N, Song WX, Luo J, Haydon RC, He TC. Osteosarcoma development and stem cell differentiation. Clin Orthop Relat Res. 2008; 466:2114-2130. [PubMed: 18563507]

14. Helman LJ, Meltzer P. Mechanisms of sarcoma development. Nat Rev Cancer. 2003; 3:685-694. [PubMed: 12951587]

15. Janeway KA, Walkley CR. Modeling human osteosarcoma in the mouse: From bedside to bench. Bone. 2010; 47:859-865. [PubMed: 20696288]

16. Jones KB. Osteosarcomagenesis: modeling cancer initiation in the mouse. Sarcoma. 2011; 2011:694136. [PubMed: 21403899] 
17. Berman SD, Calo E, Landman AS, Danielian PS, Miller ES, West JC, Fonhoue BD, Caron A, Bronson R, Bouxsein ML, Mukherjee S, Lees JA. Metastatic osteosarcoma induced by inactivation of $\mathrm{Rb}$ and $\mathrm{p} 53$ in the osteoblast lineage. Proc Natl Acad Sci U S A. 2008; 105:1185111856. [PubMed: 18697945]

18. Walkley CR, Qudsi R, Sankaran VG, Perry JA, Gostissa M, Roth SI, Rodda SJ, Snay E, Dunning P, Fahey FH, Alt FW, McMahon AP, Orkin SH. Conditional mouse osteosarcoma, dependent on p53 loss and potentiated by loss of Rb, mimics the human disease. Genes Dev. 2008; 22:16621676. [PubMed: 18559481]

19. Hong H, Takahashi K, Ichisaka T, Aoi T, Kanagawa O, Nakagawa M, Okita K, Yamanaka S. Suppression of induced pluripotent stem cell generation by the p53-p21 pathway. Nature. 2009; 460:1132-1135. [PubMed: 19668191]

20. Marion RM, Strati K, Li H, Murga M, Blanco R, Ortega S, Fernandez-Capetillo O, Serrano M, Blasco MA. A p53-mediated DNA damage response limits reprogramming to ensure iPS cell genomic integrity. Nature. 2009; 460:1149-1153. [PubMed: 19668189]

21. Rosemann M, Kuosaite V, Nathrath M, Atkinson MJ. The genetics of radiation-induced and sporadic osteosarcoma: a unifying theory? J Radiol Prot. 2002; 22:A113-116. [PubMed: 12400958]

22. Hanahan D, Weinberg RA. Hallmarks of cancer: the next generation. Cell. 2011; 144:646-674. [PubMed: 21376230]

23. Greaves M, Maley CC. Clonal evolution in cancer. Nature. 2012; 481:306-313. [PubMed: 22258609]

24. Clevers H. The cancer stem cell: premises, promises and challenges. Nat Med. 2011; 17:313-319. [PubMed: 21386835]

25. Nowell PC. The clonal evolution of tumor cell populations. Science. 1976; 194:23-28. [PubMed: 959840]

26. Lapidot T, Sirard C, Vormoor J, Murdoch B, Hoang T, Caceres-Cortes J, Minden M, Paterson B, Caligiuri MA, Dick JE. A cell initiating human acute myeloid leukaemia after transplantation into SCID mice. Nature. 1994; 367:645-648. [PubMed: 7509044]

27. Gibbs CP, Kukekov VG, Reith JD, Tchigrinova O, Suslov ON, Scott EW, Ghivizzani SC, Ignatova TN, Steindler DA. Stem-like cells in bone sarcomas: implications for tumorigenesis. Neoplasia. 2005; 7:967-976. [PubMed: 16331882]

28. Fujii H, Honoki K, Tsujiuchi T, Kido A, Yoshitani K, Takakura Y. Sphere-forming stem-like cell populations with drug resistance in human sarcoma cell lines. Int J Oncol. 2009; 34:1381-1386. [PubMed: 19360350]

29. Adhikari AS, Agarwal N, Wood BM, Porretta C, Ruiz B, Pochampally RR, Iwakuma T. CD117 and Stro-1 identify osteosarcoma tumor-initiating cells associated with metastasis and drug resistance. Cancer Res. 2010; 70:4602-4612. [PubMed: 20460510]

30. Tirino V, Desiderio V, d'Aquino R, De Francesco F, Pirozzi G, Graziano A, Galderisi U, Cavaliere C, De Rosa A, Papaccio G, Giordano A. Detection and characterization of CD133+ cancer stem cells in human solid tumours. PloS one. 2008; 3:e3469. [PubMed: 18941626]

31. Tirino V, Desiderio V, Paino F, De Rosa A, Papaccio F, Fazioli F, Pirozzi G, Papaccio G. Human primary bone sarcomas contain CD133+ cancer stem cells displaying high tumorigenicity in vivo. The FASEB journal: official publication of the Federation of American Societies for Experimental Biology. 2011; 25:2022-2030.

32. Basu-Roy U, Seo E, Ramanathapuram L, Rapp TB, Perry JA, Orkin SH, Mansukhani A, Basilico C. Sox 2 maintains self renewal of tumor-initiating cells in osteosarcomas. Oncogene. 2011; 31:2270-2282. [PubMed: 21927024]

33. Rainusso N, Man TK, Lau CC, Hicks J, Shen JJ, Yu A, Wang LL, Rosen JM. Identification and gene expression profiling of tumor-initiating cells isolated from human osteosarcoma cell lines in an orthotopic mouse model. Cancer biology \& therapy. 2011; 12:278-287. [PubMed: 21617384]

34. Murase M, Kano M, Tsukahara T, Takahashi A, Torigoe T, Kawaguchi S, Kimura S, Wada T, Uchihashi Y, Kondo T, Yamashita T, Sato N. Side population cells have the characteristics of cancer stem-like cells/cancer-initiating cells in bone sarcomas. British journal of cancer. 2009; 101:1425-1432. [PubMed: 19826427] 
35. Yang M, Yan M, Zhang R, Li J, Luo Z. Side population cells isolated from human osteosarcoma are enriched with tumor-initiating cells. Cancer Sci. 2011; 102:1774-1781. [PubMed: 21740477]

36. Honoki K, Fujii H, Kubo A, Kido A, Mori T, Tanaka Y, Tsujiuchi T. Possible involvement of stem-like populations with elevated ALDH1 in sarcomas for chemotherapeutic drug resistance. Oncol Rep. 2010; 24:501-505. [PubMed: 20596639]

37. Wang L, Park P, Zhang H, La Marca F, Lin CY. Prospective identification of tumorigenic osteosarcoma cancer stem cells in OS99-1 cells based on high aldehyde dehydrogenase activity. Int J Cancer. 2011; 128:294-303. [PubMed: 20309879]

38. Siclari VA, Qin L. Targeting the osteosarcoma cancer stem cell. J Orthop Surg Res. 2010; 5:78. [PubMed: 20979639]

39. Morikawa S, Mabuchi Y, Kubota Y, Nagai Y, Niibe K, Hiratsu E, Suzuki S, Miyauchi-Hara C, Nagoshi N, Sunabori T, Shimmura S, Miyawaki A, Nakagawa T, Suda T, Okano H, Matsuzaki Y. Prospective identification, isolation, and systemic transplantation of multipotent mesenchymal stem cells in murine bone marrow. J Exp Med. 2009; 206:2483-2496. [PubMed: 19841085]

40. Pevsner-Fischer M, Levin S, Zipori D. The origins of mesenchymal stromal cell heterogeneity. Stem cell reviews. 2011; 7:560-568. [PubMed: 21437576]

41. Kelly SE, Di Benedetto A, Greco A, Howard CM, Sollars VE, Primerano DA, Valluri JV, Claudio PP. Rapid selection and proliferation of CD133+ cells from cancer cell lines: chemotherapeutic implications. PloS one. 2010; 5:e10035. [PubMed: 20386701]

42. Li L, Clevers H. Coexistence of quiescent and active adult stem cells in mammals. Science. 2010; 327:542-545. [PubMed: 20110496]

43. Takeda N, Jain R, LeBoeuf MR, Wang Q, Lu MM, Epstein JA. Interconversion between intestinal stem cell populations in distinct niches. Science. 2011; 334:1420-1424. [PubMed: 22075725]

44. Takebe N, Harris PJ, Warren RQ, Ivy SP. Targeting cancer stem cells by inhibiting Wnt, Notch, and Hedgehog pathways. Nat Rev Clin Oncol. 2011; 8:97-106. [PubMed: 21151206]

45. Blanpain C, Mohrin M, Sotiropoulou PA, Passegue E. DNA-damage response in tissue-specific and cancer stem cells. Cell Stem Cell. 2011; 8:16-29. [PubMed: 21211780]

46. Ma I, Allan AL. The role of human aldehyde dehydrogenase in normal and cancer stem cells. Stem cell reviews. 2011; 7:292-306. [PubMed: 21103958]

47. Gangemi R, Paleari L, Orengo AM, Cesario A, Chessa L, Ferrini S, Russo P. Cancer stem cells: a new paradigm for understanding tumor growth and progression and drug resistance. Curr Med Chem. 2009; 16:1688-1703. [PubMed: 19442140]

48. Nguyen LV, Vanner R, Dirks P, Eaves CJ. Cancer stem cells: an evolving concept. Nat Rev Cancer. 2012; 12:133-143. [PubMed: 22237392]

49. Rosen JM, Jordan CT. The increasing complexity of the cancer stem cell paradigm. Science. 2009; 324:1670-1673. [PubMed: 19556499]

50. O'Brien CA, Kreso A, Jamieson CH. Cancer stem cells and self-renewal. Clin Cancer Res. 2010; 16:3113-3120. [PubMed: 20530701]

51. Reynolds BA, Weiss S. Generation of neurons and astrocytes from isolated cells of the adult mammalian central nervous system. Science. 1992; 255:1707-1710. [PubMed: 1553558]

52. Pastrana E, Silva-Vargas V, Doetsch F. Eyes wide open: a critical review of sphere-formation as an assay for stem cells. Cell Stem Cell. 2011; 8:486-498. [PubMed: 21549325]

53. Hill RP, Perris R. “Destemming” cancer stem cells. J Natl Cancer Inst. 2007; 99:1435-1440. [PubMed: 17895479]

54. Wang L, Park P, Lin CY. Characterization of stem cell attributes in human osteosarcoma cell lines. Cancer Biol Ther. 2009; 8

55. Wilson H, Huelsmeyer M, Chun R, Young KM, Friedrichs K, Argyle DJ. Isolation and characterisation of cancer stem cells from canine osteosarcoma. Vet J. 2008; 175:69-75. [PubMed: 17851099]

56. Levings PP, McGarry SV, Currie TP, Nickerson DM, McClellan S, Ghivizzani SC, Steindler DA, Gibbs CP. Expression of an exogenous human Oct-4 promoter identifies tumor-initiating cells in osteosarcoma. Cancer Res. 2009; 69:5648-5655. [PubMed: 19584295] 
57. Gibbs CP Jr, Levings PP, Ghivizzani SC. Evidence for the osteosarcoma stem cell. Curr Orthop Pract. 2011; 22:322-326. [PubMed: 21755019]

58. Reya T, Morrison SJ, Clarke MF, Weissman IL. Stem cells, cancer, and cancer stem cells. Nature. 2001; 414:105-111. [PubMed: 11689955]

59. Pittenger MF, Mackay AM, Beck SC, Jaiswal RK, Douglas R, Mosca JD, Moorman MA, Simonetti DW, Craig S, Marshak DR. Multilineage potential of adult human mesenchymal stem cells. Science. 1999; 284:143-147. [PubMed: 10102814]

60. Ducy P, Schinke T, Karsenty G. The osteoblast: a sophisticated fibroblast under central surveillance. Science. 2000; 289:1501-1504. [PubMed: 10968779]

61. Lian JB, Stein GS, Javed A, van Wijnen AJ, Stein JL, Montecino M, Hassan MQ, Gaur T, Lengner CJ, Young DW. Networks and hubs for the transcriptional control of osteoblastogenesis. Rev Endocr Metab Disord. 2006; 7:1-16. [PubMed: 17051438]

62. Olsen BR, Reginato AM, Wang W. Bone development. Annu Rev Cell Dev Biol. 2000; 16:191220. [PubMed: 11031235]

63. Thomas DM, Carty SA, Piscopo DM, Lee JS, Wang WF, Forrester WC, Hinds PW. The retinoblastoma protein acts as a transcriptional coactivator required for osteogenic differentiation. Mol Cell. 2001; 8:303-316. [PubMed: 11545733]

64. Calo E, Quintero-Estades JA, Danielian PS, Nedelcu S, Berman SD, Lees JA. Rb regulates fate choice and lineage commitment in vivo. Nature. 2010; 466:1110-1114. [PubMed: 20686481]

65. Berman SD, Yuan TL, Miller ES, Lee EY, Caron A, Lees JA. The retinoblastoma protein tumor suppressor is important for appropriate osteoblast differentiation and bone development. Mol Cancer Res. 2008; 6:1440-1451. [PubMed: 18819932]

66. Gutierrez GM, Kong E, Sabbagh Y, Brown NE, Lee JS, Demay MB, Thomas DM, Hinds PW. Impaired bone development and increased mesenchymal progenitor cells in calvaria of RB1-/mice. Proc Natl Acad Sci U S A. 2008; 105:18402-18407. [PubMed: 19020086]

67. Lengner CJ, Steinman HA, Gagnon J, Smith TW, Henderson JE, Kream BE, Stein GS, Lian JB, Jones SN. Osteoblast differentiation and skeletal development are regulated by Mdm2-p53 signaling. J Cell Biol. 2006; 172:909-921. [PubMed: 16533949]

68. Wang X, Kua HY, Hu Y, Guo K, Zeng Q, Wu Q, Ng HH, Karsenty G, de Crombrugghe B, Yeh J, $\mathrm{Li}$ B. p53 functions as a negative regulator of osteoblastogenesis, osteoblast-dependent osteoclastogenesis, and bone remodeling. J Cell Biol. 2006; 172:115-125. [PubMed: 16380437]

69. Thomas DM, Johnson SA, Sims NA, Trivett MK, Slavin JL, Rubin BP, Waring P, McArthur GA, Walkley CR, Holloway AJ, Diyagama D, Grim JE, Clurman BE, Bowtell DD, Lee JS, Gutierrez GM, Piscopo DM, Carty SA, Hinds PW. Terminal osteoblast differentiation, mediated by runx2 and p27KIP1, is disrupted in osteosarcoma. J Cell Biol. 2004; 167:925-934. [PubMed: 15583032]

70. Williams SA, Maecker HL, French DM, Liu J, Gregg A, Silverstein LB, Cao TC, Carano RA, Dixit VM. USP1 deubiquitinates ID proteins to preserve a mesenchymal stem cell program in osteosarcoma. Cell. 2011; 146:918-930. [PubMed: 21925315]

71. Wagner ER, Luther G, Zhu G, Luo Q, Shi Q, Kim SH, Gao JL, Huang E, Gao Y, Yang K, Wang L, Teven C, Luo X, Liu X, Li M, Hu N, Su Y, Bi Y, He BC, Tang N, Luo J, Chen L, Zuo G, Rames R, Haydon RC, Luu HH, He TC. Defective osteogenic differentiation in the development of osteosarcoma. Sarcoma. 2011; 2011:325238. [PubMed: 21437219]

72. Mohseny AB, Szuhai K, Romeo S, Buddingh EP, Briaire-de Bruijn I, de Jong D, van Pel M, Cleton-Jansen AM, Hogendoorn PC. Osteosarcoma originates from mesenchymal stem cells in consequence of aneuploidization and genomic loss of Cdkn2. J Pathol. 2009; 219:294-305. [PubMed: 19718709]

73. Koide Y, Morikawa S, Mabuchi Y, Muguruma Y, Hiratsu E, Hasegawa K, Kobayashi M, Ando K, Kinjo K, Okano H, Matsuzaki Y. Two distinct stem cell lineages in murine bone marrow. Stem Cells. 2007; 25:1213-1221. [PubMed: 17218403]

74. Bian ZY, Fan QM, Li G, Xu WT, Tang TT. Human mesenchymal stem cells promote growth of osteosarcoma: involvement of interleukin- 6 in the interaction between human mesenchymal stem cells and Saos-2. Cancer Sci. 2010; 101:2554-2560. [PubMed: 20874851]

75. Brune JC, Tormin A, Johansson MC, Rissler P, Brosjo O, Lofvenberg R, von Steyern FV, Mertens F, Rydholm A, Scheding S. Mesenchymal stromal cells from primary osteosarcoma are non- 
malignant and strikingly similar to their bone marrow counterparts. Int J Cancer. 2011; 129:319330. [PubMed: 20878957]

76. Long MW, Robinson JA, Ashcraft EA, Mann KG. Regulation of human bone marrow-derived osteoprogenitor cells by osteogenic growth factors. J Clin Invest. 1995; 95:881-887. [PubMed: 7860771]

77. Tare RS, Babister JC, Kanczler J, Oreffo RO. Skeletal stem cells: phenotype, biology and environmental niches informing tissue regeneration. Mol Cell Endocrinol. 2008; 288:11-21. [PubMed: 18395331]

78. Wang L, Park P, Zhang H, La Marca F, Claeson A, Valdivia J, Lin CY. BMP-2 inhibits the tumorigenicity of cancer stem cells in human osteosarcoma OS99-1 cell line. Cancer biology \& therapy. 2011; 11:457-463. [PubMed: 21178508]

79. Dvorak P, Dvorakova D, Hampl A. Fibroblast growth factor signaling in embryonic and cancer stem cells. FEBS Lett. 2006; 580:2869-2874. [PubMed: 16516203]

80. Beenken A, Mohammadi M. The FGF family: biology, pathophysiology and therapy. Nat Rev Drug Discov. 2009; 8:235-253. [PubMed: 19247306]

81. Marie PJ, Coffin JD, Hurley MM. FGF and FGFR signaling in chondrodysplasias and craniosynostosis. J Cell Biochem. 2005; 96:888-896. [PubMed: 16149058]

82. Mansukhani A, Bellosta P, Sahni M, Basilico C. Signaling by fibroblast growth factors (FGF) and fibroblast growth factor receptor 2 (FGFR2)-activating mutations blocks mineralization and induces apoptosis in osteoblasts. J Cell Biol. 2000; 149:1297-1308. [PubMed: 10851026]

83. Mansukhani A, Ambrosetti D, Holmes G, Cornivelli L, Basilico C. Sox2 induction by FGF and FGFR2 activating mutations inhibits Wnt signaling and osteoblast differentiation. J Cell Biol. 2005; 168:1065-1076. [PubMed: 15781477]

84. Dailey L, Ambrosetti D, Mansukhani A, Basilico C. Mechanisms underlying differential responses to FGF signaling. Cytokine Growth Factor Rev. 2005; 16:233-247. [PubMed: 15863038]

85. Go MJ, Takenaka C, Ohgushi H. Effect of forced expression of basic fibroblast growth factor in human bone marrow-derived mesenchymal stromal cells. J Biochem. 2007; 142:741-748. [PubMed: 17956905]

86. Wiedlocha A, Falnes PO, Rapak A, Munoz R, Klingenberg O, Olsnes S. Stimulation of proliferation of a human osteosarcoma cell line by exogenous acidic fibroblast growth factor requires both activation of receptor tyrosine kinase and growth factor internalization. Mol Cell Biol. 1996; 16:270-280. [PubMed: 8524304]

87. Baird K, Davis S, Antonescu CR, Harper UL, Walker RL, Chen Y, Glatfelter AA, Duray PH, Meltzer PS. Gene expression profiling of human sarcomas: insights into sarcoma biology. Cancer Res. 2005; 65:9226-9235. [PubMed: 16230383]

88. Shimizu T, Ishikawa T, Iwai S, Ueki A, Sugihara E, Onishi N, Kuninaka S, Miyamoto T, Toyama Y, Ijiri H, Mori H, Matsuzaki Y, Yaguchi T, Nishio H, Kawakami Y, Ikeda Y, Saya H. Fibroblast Growth Factor-2 Is an Important Factor that Maintains Cellular Immaturity and Contributes to Aggressiveness of Osteosarcoma. Mol Cancer Res. 2012

89. Baron R, Rawadi G, Roman-Roman S. Wnt signaling: a key regulator of bone mass. Curr Top Dev Biol. 2006; 76:103-127. [PubMed: 17118265]

90. Krishnan V, Bryant HU, Macdougald OA. Regulation of bone mass by Wnt signaling. J Clin Invest. 2006; 116:1202-1209. [PubMed: 16670761]

91. Moon RT, Bowerman B, Boutros M, Perrimon N. The promise and perils of Wnt signaling through beta-catenin. Science. 2002; 296:1644-1646. [PubMed: 12040179]

92. Matushansky I, Hernando E, Socci ND, Mills JE, Matos TA, Edgar MA, Singer S, Maki RG, Cordon-Cardo C. Derivation of sarcomas from mesenchymal stem cells via inactivation of the Wnt pathway. J Clin Invest. 2007; 117:3248-3257. [PubMed: 17948129]

93. Matushansky, Maki RG, Cordon-Cardo C. A context dependent role for Wnt signaling in tumorigenesis and stem cells. Cell Cycle. 2008; 7:720-724. [PubMed: 18239459]

94. Kansara M, Tsang M, Kodjabachian L, Sims NA, Trivett MK, Ehrich M, Dobrovic A, Slavin J, Choong PF, Simmons PJ, Dawid IB, Thomas DM. Wnt inhibitory factor 1 is epigenetically silenced in human osteosarcoma, and targeted disruption accelerates osteosarcomagenesis in mice. J Clin Invest. 2009; 119:837-851. [PubMed: 19307728] 
95. Cai Y, Mohseny AB, Karperien M, Hogendoorn PC, Zhou G, Cleton-Jansen AM. Inactive Wnt/ beta-catenin pathway in conventional high-grade osteosarcoma. J Pathol. 2010; 220:24-33. [PubMed: 19882675]

96. Cleton-Jansen AM, Anninga JK, Briaire-de Bruijn IH, Romeo S, Oosting J, Egeler RM, Gelderblom H, Taminiau AH, Hogendoorn PC. Profiling of high-grade central osteosarcoma and its putative progenitor cells identifies tumourigenic pathways. Br J Cancer. 2009; 101:1909-1918. [PubMed: 19888226]

97. Vijayakumar S, Liu G, Rus IA, Yao S, Chen Y, Akiri G, Grumolato L, Aaronson SA. Highfrequency canonical Wnt activation in multiple sarcoma subtypes drives proliferation through a TCF/beta- catenin target gene, CDC25A. Cancer Cell. 2011; 19:601-612. [PubMed: 21575861]

98. Bisson I, Prowse DM. WNT signaling regulates self-renewal and differentiation of prostate cancer cells with stem cell characteristics. Cell Res. 2009; 19:683-697. [PubMed: 19365403]

99. Kanwar SS, Yu Y, Nautiyal J, Patel BB, Majumdar AP. The Wnt/beta-catenin pathway regulates growth and maintenance of colonospheres. Mol Cancer. 2010; 9:212. [PubMed: 20691072]

100. Paranjape AN, Mandal T, Mukherjee G, Kumar MV, Sengupta K, Rangarajan A. Introduction of SV40ER and hTERT into mammospheres generates breast cancer cells with stem cell properties. Oncogene. 2012; 31:1896-909. [PubMed: 21874052]

101. Yu Y, Kanwar SS, Patel BB, Oh PS, Nautiyal J, Sarkar FH, Majumdar AP. MicroRNA-21 induces stemness by downregulating transforming growth factor beta receptor 2 (TGFbetaR2) in colon cancer cells. Carcinogenesis. 2012; 33:68-76. [PubMed: 22072622]

102. Pece S, Tosoni D, Confalonieri S, Mazzarol G, Vecchi M, Ronzoni S, Bernard L, Viale G, Pelicci PG, Di Fiore PP. Biological and molecular heterogeneity of breast cancers correlates with their cancer stem cell content. Cell. 2010; 140:62-73. [PubMed: 20074520]

103. Tang QL, Zhao ZQ, Li JC, Liang Y, Yin JQ, Zou CY, Xie XB, Zeng YX, Shen JN, Kang T, Wang J. Salinomycin inhibits osteosarcoma by targeting its tumor stem cells. Cancer Lett. 2011; 311:113-121. [PubMed: 21835542]

104. Rainusso N, Brawley VS, Ghazi A, Hicks MJ, Gottschalk S, Rosen JM, Ahmed N. Immunotherapy targeting HER2 with genetically modified $\mathrm{T}$ cells eliminates tumor-initiating cells in osteosarcoma. Cancer Gene Ther. 2012; 19:212-217. [PubMed: 22173710]

105. Brattain MG, Fine WD, Khaled FM, Thompson J, Brattain DE. Heterogeneity of malignant cells from a human colonic carcinoma. Cancer Res. 1981; 41:1751-1756. [PubMed: 7214343]

106. Fuerer C, Nusse R. Lentiviral vectors to probe and manipulate the Wnt signaling pathway. PLoS One. 2010; 5:e9370. [PubMed: 20186325] 


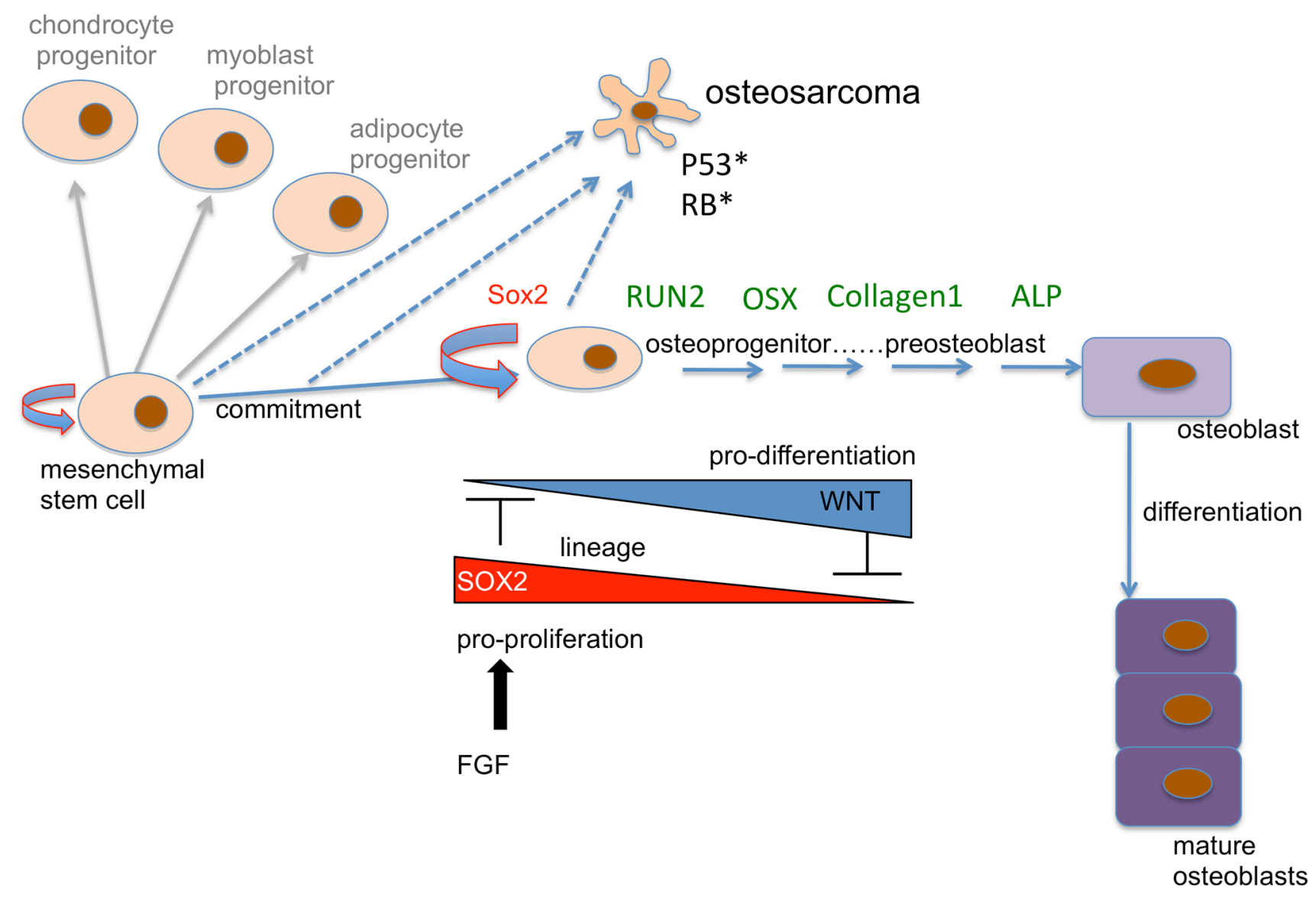

Figure 1. Schematic of the commitment of MSCs and progression of the osteoblast lineage Markers of osteoblast commitment and differentiation are in green $=$ Runx2, osterix (osx), collagen1, alkaline phosphatase (ALP). Self-renewal of MSCs and osteoprogenitors (curved arrows). Sox 2 decreases and Wnt signaling increases as differentiation progresses. Sox 2 is expressed in MSC and immature osteoprogenitors. Osteosarcomas are thought to originate from multipotent MSCs, or progenitors in the osteoblast lineage that still retain bipotency. Osteosarcoma induction is promoted by $\mathrm{Rb}$ and p53 inactivation (*). 
A

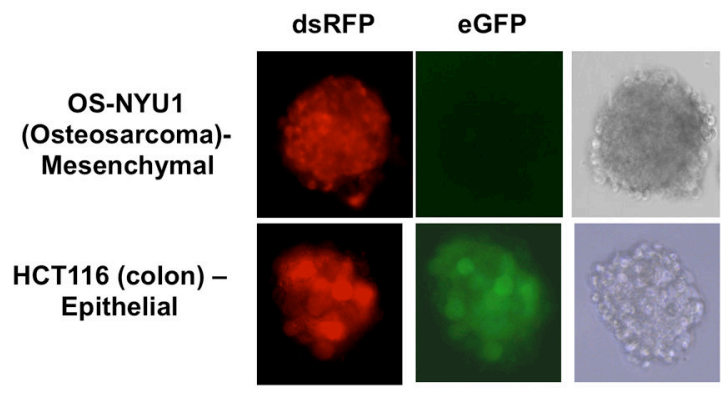

B

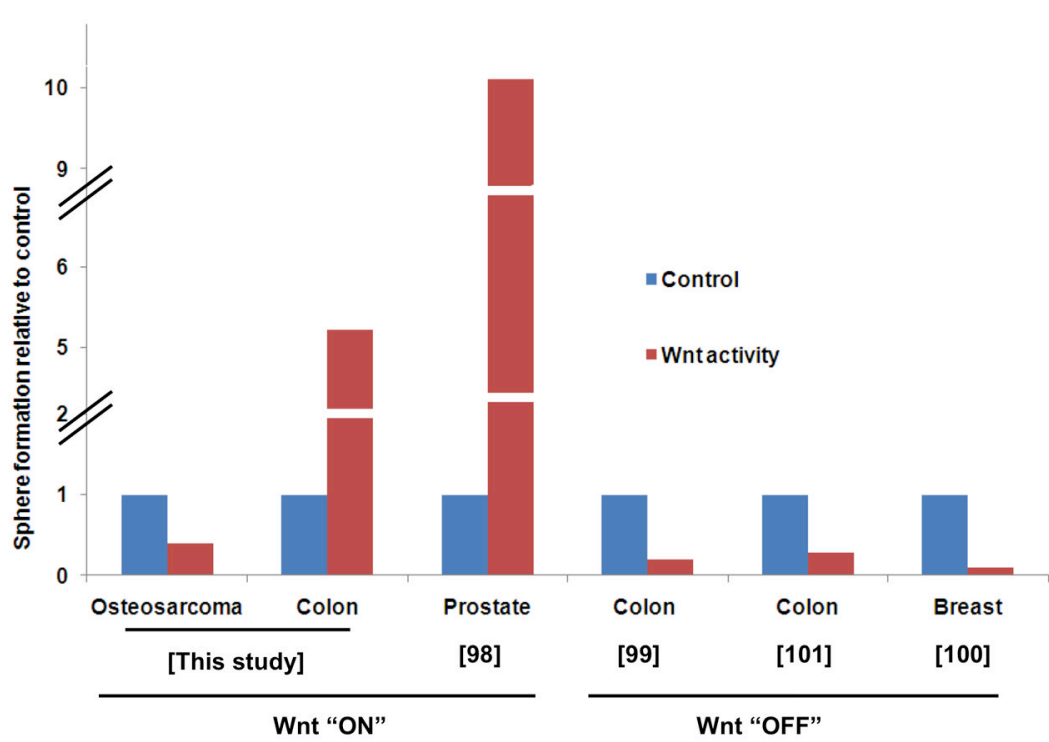

Figure 2. Opposite Wnt activity in epithelial and mesenchymal CSCs (sphere forming cells) A. Spheres of osteosarcoma (OS-NYU1) [32] and colon cancer (HCT116) [105] cells expressing a Wnt-eGFP reporter that is also marked with RFP [106]. Wnt activity in the sphere is evident by expression of eGFP (green). dsRFP expression (red) measures transduction efficiency of the reporter. B. Composite data showing relative sphere formation in osteosarcoma and epithelial tumors (colon and prostrate) before (control) and following canonical Wnt activation ("ON") or inhibition ("OFF"). Data for epithelial tumors have been adapted from references $[98 ; 99 ; 100 ; 101]$. Data for the osteosarcoma cell line was generated by treating the OS-NYU1 cell line with the Wnt activator (CHIR99201) and assaying sphere formation. 


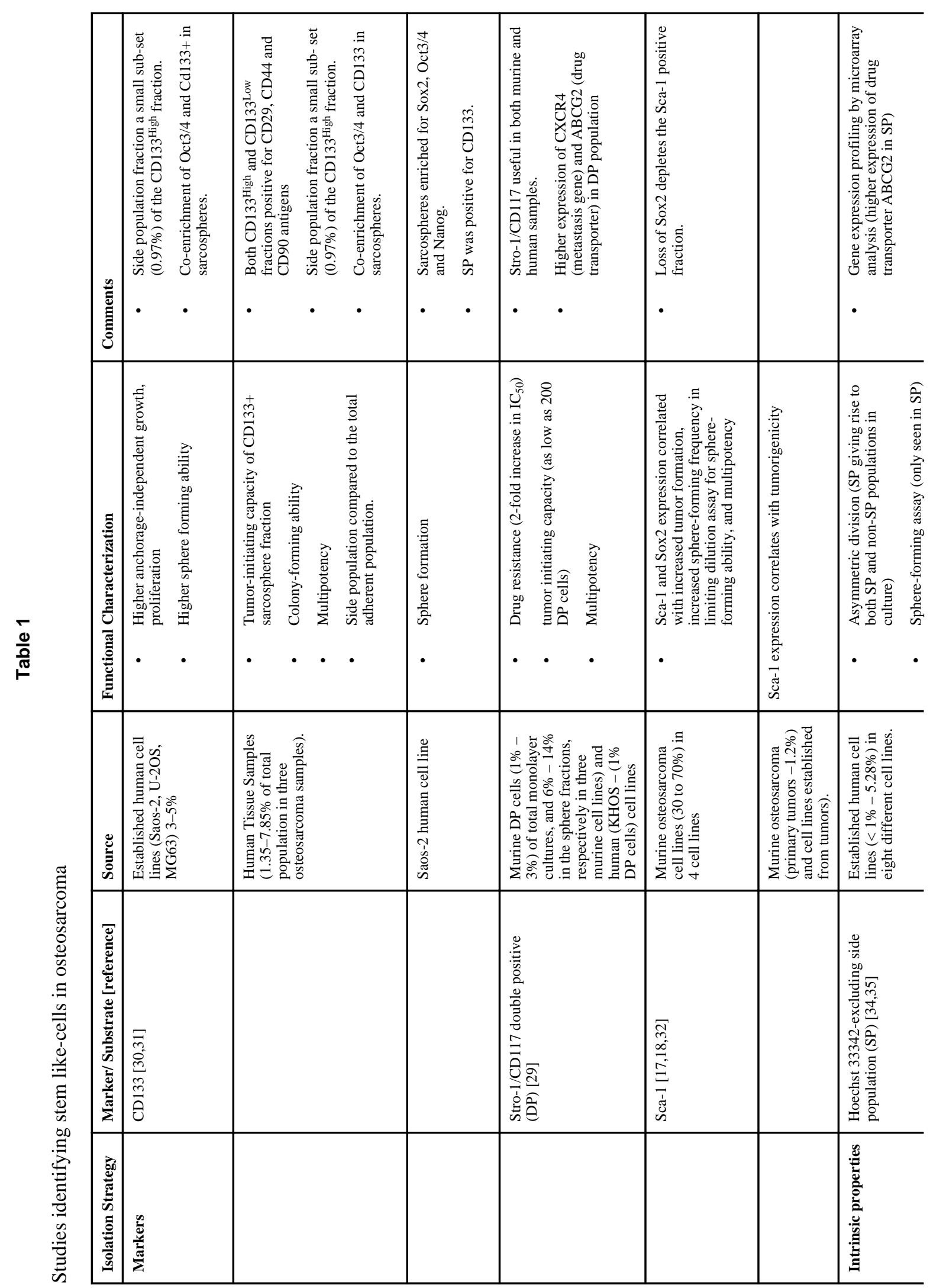




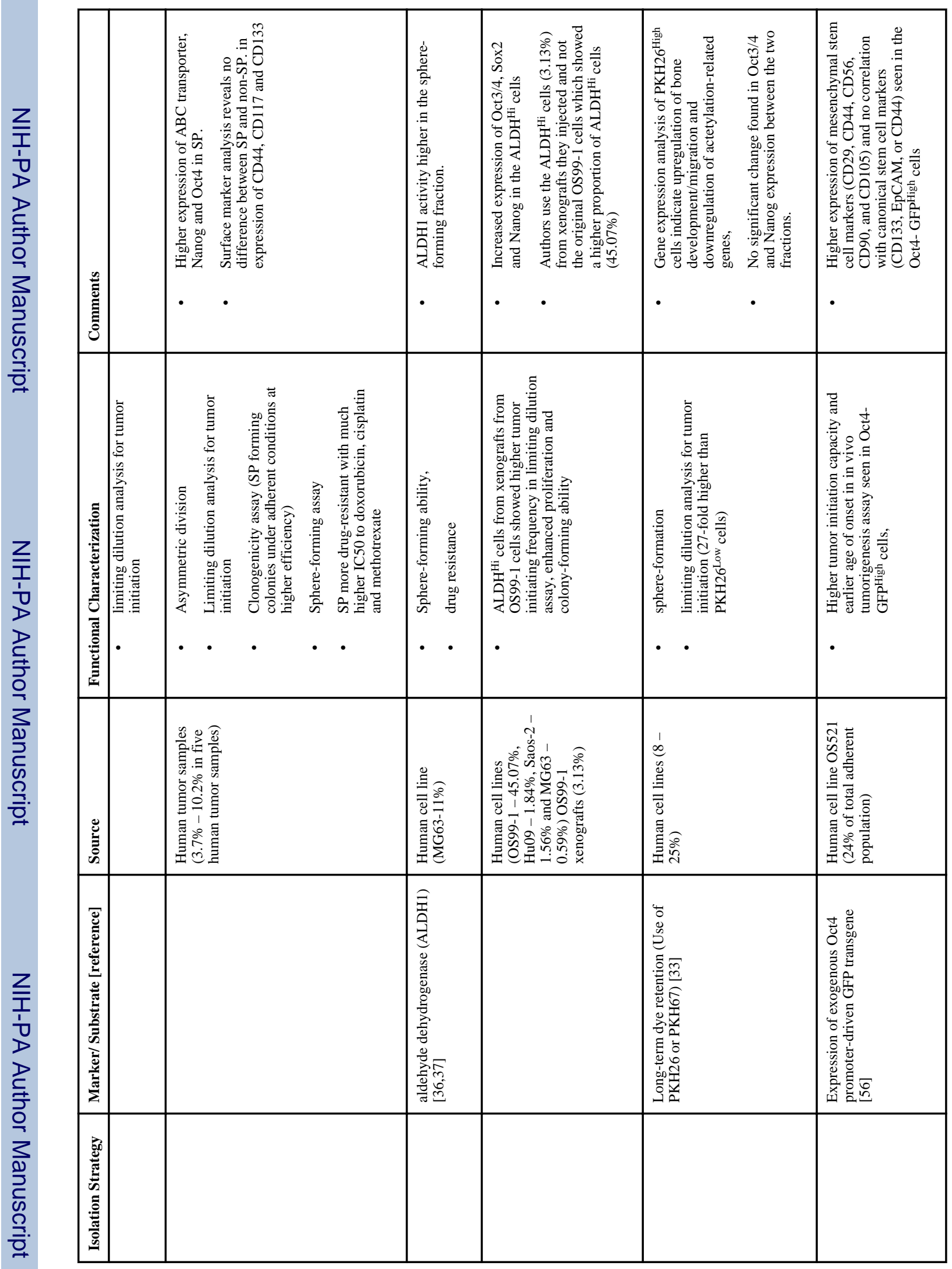

